\title{
Energy Literacy of Junior High School Students in Indonesia: A Preliminary Study
}

\author{
Musawwir Usman ${ }^{1, *}$ Suyanta $^{2}$ Pujianto ${ }^{3,}$ Khoirul Huda ${ }^{1,}$ \\ ${ }^{1}$ Master of Natural Science Education, Faculty of Mathematics and Natural Sciences, Universitas Negeri \\ Yogyakarta, Indonesia \\ ${ }^{2}$ Department of Chemistry Education, Faculty of Mathematics and Natural Sciences, Universitas Negeri \\ Yogyakarta, Indonesia \\ ${ }^{3}$ Department of Physics Education, Faculty of Mathematics and Natural Sciences, Universitas Negeri \\ Yogyakarta, Indonesia \\ *Corresponding author. Email: musawwirusman.2019@student.uny.ac.id
}

\begin{abstract}
Energy plays an essential role in the development of a country, including Indonesia, both in the social and economic sector and the quality of its citizen life. However, Indonesian still used energy in an ineffective way. One of the best ways to instill energy-saving behavior for citizens is by improving their energy literacy. This study aims to discover the initial energy literacy profile of junior high school students in Indonesia. The research design used was a quantitative descriptive design with an open survey method. The research was conducted online in October 2020. There were 184 students (95 males and 89 females) in $8^{\text {th }}$ and $9^{\text {th }}$ grades that chosen using simple random sampling technique with the snowball method. The data was collected using a modified energy literacy questionnaire. The results indicate that Indonesian junior high school students' energy literacy belongs to moderate category, with a discouragingly low average cognitive domain score. This is because students are concerned about energy problems and their positive attitudes, but they apparently lack the required knowledge and skills to contribute toward energy-related issues. Therefore, it is necessary to develop learning method that is able to hone student's energy literacy and synergize its domains, such as STEM-based learning.
\end{abstract}

Keywords: Energy education, Energy literacy, Junior high school students

\section{INTRODUCTION}

Energy production and consumption are one of the government's concerns, including in Indonesia. The total electrical energy production in Indonesia from various sources is $254 \mathrm{TWh}$, while the total electricity consumption is $223 \mathrm{TWh}$ [1]. Indonesia's electricity consumption per capita $(\mathrm{kWh})$ of 1.021 is still deficient when compared to other countries, such as Singapore (8.70 kWh), Malaysia (4.90 kWh), and Thailand (2,70 kWh) [2]. Also, Indonesia's energy consumption is still focused on the residential sector with $41.2 \%$, while the industrial sector is only $32.4 \%$ [1], [3]. It is still inefficient when compared to other countries that focus more on the industrial sector, such as Singapore (40.5\%) and Malaysia (48.7\%) [1]. It means that Indonesian citizens still used energy in an ineffective way compared to citizens in other countries.
Inefficient energy use will cause various negative impacts, such as increasing global temperature, causing extreme weather, and reducing electricity supply for the future, significantly when various energy sources are decreasing, and environmental conditions are getting worse [4]. The issue of energy use is not only the responsibility of the governments and experts but also the responsibility of every citizen who participates in society. The government can make many efforts in solving the energy-related problem, such as switching to alternative fuels and constructing power plants using renewable energy sources. In addition to government efforts, citizens can also contribute to solving energy-related issues, such as enhancing their energy literacy [4], [5]. Energy Literacy Advocates claim that the most excellent potential resource for meeting our national energy crisis is energy literacy. An informed, the energyliterate public will be better equipped to make 
thoughtful, responsible energy-related decisions and actions [4].

Energy literacy is an understanding of the nature and role of energy in the universe and our lives, and also a skill to apply this understanding to answer questions and solve problems[6]. Energy literacy does not include cognitive domain only, but also affective and behavioral domains [4], [7], which impacts the understanding and attitudes towards energy and its use from a society perspective [8], [9]. A study about the profile of student's energy literacy has been done by experts from abroad. Prior research results showed that energy literacy was low among junior high school students in New York State, USA [4], Greece [10], Malaysia [11], and Taiwan [12], energy literacy among Japanese students also failed to meet the ideal criterion of 70\% [5] and Canadian students performed an unsatisfactory level of energy literacy [13]. However, studies about energy literacy in Indonesia is still not being highlighted by experts in Indonesia. Energy literacy among Indonesian students was low based on each indicator, especially energy use in daily life, energy-saving attitudes, energy conservation [14], understanding the effect of developing, applying, and using energy sources [15]. However, those findings do not cover the energy literacy profile of Indonesian junior high school students overall. Therefore, research about energy literacy profile of Indonesian junior high school students is necessary.
This study is looking for Indonesian junior high school students' initial energy literacy profile because energy literacy is an essential ability for students to ensure a sustainable energy future. Therefore, this study is expected to significantly contribute to understanding the importance of energy literacy for the students. This study is hoped to be an initial reference for the government, teachers, or students to develop energy literacy.

\section{RESEARCH METHOD}

This research used a descriptive quantitative design with an open survey method. This design was used because this research aims to find out and describe the initial energy literacy profile of junior high school students in Indonesia by emphasizing quantitative data. This research was established online in October 2020. The sampling technique used is simple random sampling with the snowball method. There were 184 Indonesian Junior High School students ( 95 males and 89 females) in $8^{\text {th }}$ and $9^{\text {th }}$ grades who enrolled in this research. The data was collected using an energy literacy questionnaire, developed and modified from the questionnaire of the prior researches [5], [16], [17], consisting of 50 items, which can be seen in detail in table 1 .

Table 1. Description of modified energy literacy questionnaire

\begin{tabular}{|c|c|c|c|c|}
\hline Domain & Aspect & $\begin{array}{l}\text { Total } \\
\text { item }\end{array}$ & Type & Score \\
\hline \multirow[t]{5}{*}{ Cognitive } & Basic energy knowledge & 7 & \multirow{5}{*}{$\begin{array}{l}\text { Test with } 4 \\
\text { choices }\end{array}$} & \multirow{5}{*}{$\begin{array}{l}\text { Correct }=1 \\
\text { Wrong }=0 \\
\text { Blank }=0\end{array}$} \\
\hline & Energy resource issues & 5 & & \\
\hline & Common trends of energy in Indonesia & 3 & & \\
\hline & $\begin{array}{l}\text { Impact of individual and societal decisions } \\
\text { related to energy }\end{array}$ & 5 & & \\
\hline & Cognitive skills & 5 & & \\
\hline \multirow[t]{4}{*}{ Affective } & Awareness/concern toward energy & 4 & \multirow{4}{*}{$\begin{array}{l}\text { A questionnaire } \\
\text { with } 5 \text { Likert-scale } \\
\text { responses. }\end{array}$} & \multirow{4}{*}{$\begin{array}{l}1 \text { (least preferred } \\
\text { response) to } 5 \text { (most } \\
\text { preferred response) }\end{array}$} \\
\hline & Positive attitudes, norms, and values & 4 & & \\
\hline & Strong efficacy beliefs & 4 & & \\
\hline & Responsibility & 3 & & \\
\hline \multirow[t]{2}{*}{ Behavioral } & Energy-saving behavior & 7 & \multirow{2}{*}{$\begin{array}{l}\text { A questionnaire } \\
\text { with } 5 \text { Likert-scale } \\
\text { responses. }\end{array}$} & \multirow{2}{*}{$\begin{array}{l}1 \text { (least preferred } \\
\text { response) to } 5 \text { (most } \\
\text { preferred response) }\end{array}$} \\
\hline & Thoughtful, effective decision making & 3 & & \\
\hline
\end{tabular}


The questionnaire used had been validated by experts. The quantitative descriptive analysis was performed to analyze and determine the category of energy literacy of each student. The analysis data and category of energy literacy can be seen in table 2 [14], but the "High" category was modified using the ideal criterion for an energy-literate person [5].

Table 2. The category of energy literacy

\begin{tabular}{|c|c|c|}
\hline No. & Percentage $(\%)$ & Category \\
\hline 1. & $95,00<\mathrm{N} \leq 100,00$ & Special \\
\hline 2. & $80,00<\mathrm{N} \leq 95,00$ & Very High \\
\hline 3. & $70,00<\mathrm{N} \leq 80,00$ & High \\
\hline 4. & $55,00<\mathrm{N} \leq 70,00$ & Moderate \\
\hline 5. & $40,00<\mathrm{N} \leq 55,00$ & Low \\
\hline 6. & $0,00<\mathrm{N} \leq 40,00$ & Very Low \\
\hline
\end{tabular}

\section{RESULTS AND DISCUSSION}

A performance summary for the cognitive, affective, and behavioral domain for Indonesian junior high school students is presented in table 3 . The results in table 3 indicate that Indonesian junior high school students' energy literacy is discouragingly low, particularly concerning their performance in cognitive domain. Students' energy literacy performance on each domain is scoring highest on affective domain and lowest on cognitive domain.

Table 3. General description of student's energy literacy

\begin{tabular}{|l|c|c|c|}
\hline & Cognitive & Affective & Behavioral \\
\hline Sample: & \multicolumn{3}{|c|}{194} \\
\hline 1) Male & \multicolumn{3}{|c|}{95} \\
\hline 2) Female & \multicolumn{3}{|c|}{89} \\
\hline Median (\%) & 48.00 & 81.33 & 74.00 \\
\hline Mean (\%) & 48.61 & 80.87 & 73.79 \\
\hline SD (\%) & 13.82 & 12.84 & 13.60 \\
\hline
\end{tabular}

These findings are consistent with the previous finding, where it was found that cognitive domain means $42 \%$, affective domain means $73 \%$, and behavioral domain means $65 \%$ [4]. Similar findings also are acquired by another research, where cognitive domain means $32,66 \%$, affective domain means $72,87 \%$, and behavioral domain means $71,38 \%$ [11]. These research findings indicate that students are concerned about energy problems and their positive attitudes toward energy, but they apparently may lack the required knowledge and skills to contribute toward energy-related problems and solutions effectively.
This is because energy-related education has not been paid much attention, so there is no energy education program that is able to synergize the three domains in energy literacy.

The distribution of the energy literacy category and the number of students can be seen in figure 1. Based on figure 1 , students who have very high energy literacy are only 18 students $(9,78 \%)$, high energy literacy is 58 students $(31,52 \%)$, moderate energy literacy is 83 students $(45,11 \%)$, low energy literacy is 25 students $(13,59 \%)$, and there is no student in the special and very low category. These findings indicate that the number of students who meet the energyliterate person's standard criteria is still small $(<50 \%)$. This is due to the lack of education that encourages understanding related to energy and the lack of student interest in energy learning. Thus, it is essential to provide energy education for students because education can allow them to familiarize themselves, develop their awareness, transform their behavior toward an energy-related topic, and increase their energy literacy [18]. In Indonesia, energy education can be integrated into physics learning to foster students' energy literacy [19].

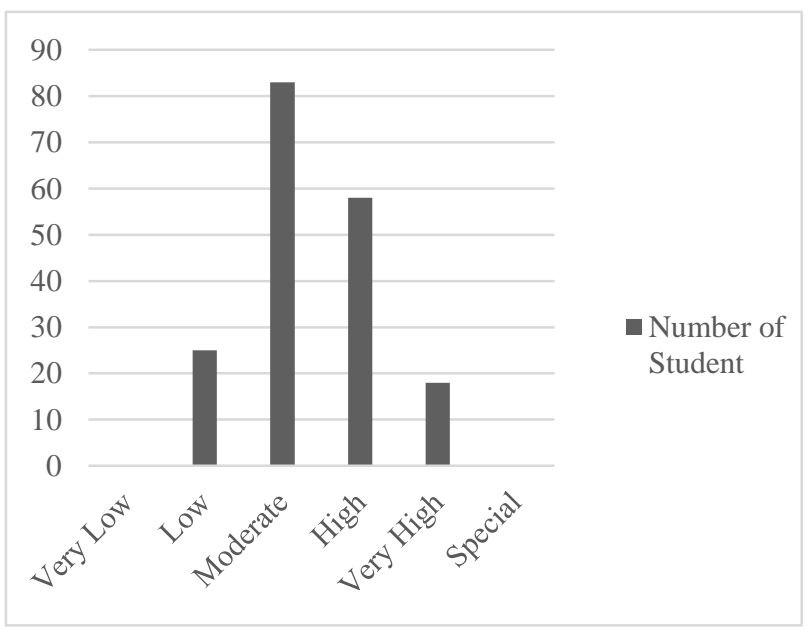

Figure 1 The distribution of energy literacy category and number of students

The result about student's energy literacy on each aspect is presented in Table 4. The cognitive domain result distribution for basic energy knowledge is moderate with percentage of $65,53 \%$; energy resource issues is low with percentage of $42,83 \%$, common trends of energy in Indonesia is low with percentage of $44,75 \%$, impact of individual and societal decisions related to energy is low with percentage $41,30 \%$ and cognitive skills is low with percentage $41,41 \%$. The affective domain result distribution for awareness/concern toward energy is very high with 
percentage of $82,04 \%$, positive attitudes, norms and values is very high with percentage of $81,44 \%$, strong efficacy beliefs is high with percentage of $76,71 \%$ and responsibility is very high with percentage $84,09 \%$.
The behavioral domain result distribution for energysaving behavior is high with a percentage of $78,06 \%$, and thoughtful, effective decision-making is moderate with a $63,84 \%$ percentage.

Table 4. Results of student's energy literacy for each indicator

\begin{tabular}{|l|l|c|c|}
\hline \multicolumn{1}{|c|}{ Domain } & \multicolumn{1}{|c|}{ Aspect } & Results (\%) & Category \\
\hline \multirow{5}{*}{ Cognitive } & Basic energy knowledge & 65.53 & Moderate \\
\cline { 2 - 4 } & Energy resource issues & 42.83 & Low \\
\cline { 2 - 4 } & Common trends of energy in Indonesia & 44.75 & Low \\
\cline { 2 - 4 } & Impact of individual and societal decisions related to energy & 41.30 & Low \\
\cline { 2 - 4 } & Cognitive skills & 41.41 & Low \\
\hline \multirow{5}{*}{ Affective } & Awareness/concern toward energy & 82.04 & Very High \\
\cline { 2 - 4 } & Positive attitudes, norms, and values & 81.44 & Very High \\
\cline { 2 - 4 } & Strong efficacy beliefs & 76.71 & High \\
\cline { 2 - 4 } & Responsibility & 74.09 & Very High \\
\hline \multirow{3}{*}{ Behavioral } & Energy-saving behavior & 63.84 & Hodigh \\
\cline { 2 - 4 } & Thoughtful, effective decision making & & Moderate \\
\hline
\end{tabular}

The low percentage of aspects in the cognitive domain found in this study is consistent with prior research, where basic energy knowledge is $21 \%$, understanding of energy sources and their relationship is $22 \%$, knowing trends in energy use in Indonesia and global energy sources-supply and use is $22 \%$, know the consequences of individual and social decisions associated with the development of energy sources is $21 \%$, and the ability to analyze, interpret, evaluate and the test is $19 \%$ [15]. Other studies also found that students were unable to correctly answer questions about the use of energy in daily life, energy-saving behavior, energy conservation, and its impact [14].

Based on data, it is found that student's awareness and positive attitudes toward energy belong to a very high category. Consistently with earlier findings, students generally aware and acknowledge the existence of energy issues, concern about energy conservation and renewable resource use, and have apparent positive attitudes and values towards energy [11]. Student's strong efficacy beliefs have the lowest percentage in affective domain because students claim that they cannot contribute to solving energy-related issues and take responsibility like other "capable" students. The responsibility aspect has the highest percentage in this study. Nevertheless, based on prior research findings, it indicates that despite students feel the responsibility to energy saving on a conceptual basis, if students do not understand that their behavior contributes to solving the energy-related issue, they may ignore energy-use awareness in daily life [20].

Based on the findings, although students get high scores on affective domain, their responses on behavioral domain did not generally reflect their answer on affective domain. In line with prior research, it declares a difference between students' positive attitudes and actions they take [11]. Similar findings were also found, where energy-saving behavior aspect shows that there are $52 \%$ of students try to conserve water, $65 \%$ of students turn lights off when they leave a room, $39 \%$ of students turn off their computer when it is not being used, $40 \%$ students use compact fluorescent light bulbs, and only $24 \%$ students think about energy as they make decisions throughout the day [21]. It is generally admitted that behavior must be modified to ensure a sustainable energy future because energy plays an essential role in economic and social development and the improvement of life quality in all countries [10].

These preliminary findings indicate that increasing energy literacy in schools for students is necessary and emphasize research and development on energy topics expected to establish an effective energy education program for students, which focuses not only on basic energy knowledge but also advanced energy knowledge, positive attitudes, and their energy-related behavior as well. The energy literacy of students can 
be developed through the learning process. Following up on this research, it suggests applying appropriate learning to enhance student's energy literacy. The learning method that teachers can apply is STEM education, in line with findings of prior research, student's understanding of energy literacy can be enhanced with average achievement [15].

\section{CONCLUSION}

Based on the results, it can be concluded that junior high school students' energy literacy in Indonesia is discouragingly low, particularly concerning their cognitive domain performance. Students' energy literacy performance on each domain is scoring highest on affective domain and lowest on cognitive domain. These research findings indicate that students are concerned about energy problems and their positive attitudes toward energy, but they apparently may lack the required knowledge and skills to contribute toward energy-related problems and solutions effectively. For overall energy literacy, Indonesian junior high school students belong to the moderate category. There are six aspects of energy literacy included in the low and moderate category: basic energy knowledge; energy resourse issues; common trends of energy in Indonesia; impact of individual and societal decisions related to energy; cognitive skills; and thoughtful, effective decision making. It means that their answer on cognitive domain and responses on behavioral domain did not generally reflect their answer on affective domain. Thus, energy-related education that can hone students' energy literacy and synergize its domains needs to develop to improve students' energy literacy, especially in Indonesia.

\section{ACKNOWLEDGMENTS}

The author would like to thank LPDP, which had provided both material and moral assistance for the author to carry out studies and conduct research.

\section{REFERENCES}

[1] International Energy Agency, Data tables - Data \& Statistics - IEA, International Energy Agency. Jul. 2017. Accessed on: Jan. 15, 2020. [Online]. Available: $\quad$ https://www.iea.org/data-andstatistics/datatables?country=CONGOREP\&energy=Oil\&year $=2017$
[2] PwC Indonesia, Power in Indonesia: Investment and Taxation Guide ( $6^{\text {th }}$ ed.), PwC Indonesia, 2017.

[3] Ministry of Energy and Mineral Resources, Handbook of Energy \& Economic Statistics of Indonesia 2018 Final Edition, Ministry of Energy and Mineral Resources, 2018.

[4] J. DeWaters, S. Powers, Energy Literacy of Secondary Students in New York State (USA): A Measure of Knowledge, Affect, and Behavior, Energy Policy 39(3) (2011) 1699-1710. DOI: https://doi.org/10.1016/j.enpol.2010.12.049

[5] Y. Akitsu, K.N. Ishihara, An Integrated Model Approach: Exploring The Energy Literacy and Values of Lower Secondary Students in Japan, International Journal of Educational Methodology 4(3) (2018) 161-186. DOI: https://doi.org/10.12973/ijem.4.3.161

[6] Department of Energy, Energy Literacy Essential Principles and Fundamental Concepts for Energy Education, Department of Energy, 2017.

[7] L. S. Lee, Y. F. Lee, J. W. Altschuld, Y. J. Pan, Energy literacy: Evaluating knowledge, affect, and behavior of students in Taiwan, Energy Policy 76(1) (2015) 98-106. DOI: https://doi.org/10.1016/j.enpol.2014.11.012

[8] J. DeWaters, S. Powers, Establishing Measurement Criteria for An Energy Literacy Questionnaire, The Journal of Environmental Education 44(1) (2013) 38-55. DOI: https://doi.org/10.1080/00958964.2012.711378

[9] I. Aguirre-Bielschowsky, R. Lawson, J. Stephenson, S. Todd, Energy Literacy and Agency of New Zealand Children, Environmental Education Research 23(6) (2017) 832-854.

DOI: https://doi.org/10.1080/13504622.2015.1054267

[10] E. Ntona, G. Arabatzis, G.L. Kyriakopoulos, Energy Saving: Views and Attitudes of Students in Secondary Education, Renewable and Sustainaible Energy Review 46(1) (2015) 1-15. DOI: https://doi.org/10.1016/j.rser.2015.02.033

[11] L.Y. Fah, K.C. Hoon, E.T. Munting, C.A. Chong, Secondary School Students' Energy Literacy: Effect of Gender and School Location, OIDA International Journal of Sustainable Development 3(7) (2012) 75-86. 
[12] K.L. Chen, S.H. Huang, S.Y. Liu, P.H. Chen, Energy literacy of secondary students in Taiwan: a computer-based assessment, in: Proceeding of The Third International Conference on ELearning and E-Technologies in Education, vol. 3, SDIWC, Hongkong, 2014, pp. 87-96.

[13] L.H. Barrow, J.T. Morrisey, Energy Literacy of Ninth - Grade Students: A Comparison between Maine and New Brunswick, The Journal of Environmental Education 20(2) (1989) 22-25. DOI:

https://doi.org/10.1080/00958964.1989.9943027

[14] L. Maknuniyah, S. Astutik, I. Wicaksono, Pengaruh Model Pembelajaran Collaborative Creativity ( CC ) terhadap Kemampuan Literasi Energi pada Siswa SMA, Jurnal Pembelajaran Fisika 8(2) (2019) 87-93. DOI: https://doi.org/10.19184/jpf.v8i2.11669

[15] I. Mustain, Y. Herlina, STEM for Establishing Energy Literacy in Maritime Vocational Education, Scientiae Educatia: Jurnal Pendidikan Sains 8(2) (2019) 131-140. DOI: https://doi.org/10.24235/sc.educatia.v8i2.5520

[16] J. DeWaters, B. Qaqish, M. Graham, S. Powers, Designing An Energy Literacy Questionnaire for Middle and High School Youth, The Journal of Environmental Education 44(1) (2013) 56-78. DOI:

https://doi.org/10.1080/00958964.2012.682615

[17] K.L. Chen, S.H. Huang, S.Y. Liu, Devising A Framework for Energy Education in Taiwan Using The Analytic Hierarchy Process, Energy Policy 55(1) (2013) 396-403. DOI: https://doi.org/10.1016/j.enpol.2012.12.025.

[18] N. Zografakis, A.N. Menegaki, K.P. Tsagarakis, Effective Education for Energy Efficiency, Energy Policy 36(8) (2008) 3226-3232. DOI: https://doi.org/10.1016/j.enpol.2008.04.021

[19] S. Sukendar, A. Setiawan, High School Physics Teacher's Profile in Teaching for Improving Student's Energy Literacy, Journal of Science Education Research 2(1) (2018) 25-30. DOI: https://doi.org/10.21831/jser.v2i1.19330

[20] Y. Akitsu, K. Ishihara, H. Okumura, E. Yamasue, Investigating Energy Literacy and Its Structural Model for Lower Secondary Students in Japan, International Journal of Environmental and Science Education 12(5) (2017) 1067-1095.
[21] J. DeWaters, S. Powers, Energy literacy among middle and high school youth, in: Proceeding of The 38th Annual Frontiers in Education Conference, vol. 38, IEEE, Piscataway, New Jersey, 2008, pp. 6-11. DOI: https://doi.org/10.1109/FIE.2008.4720280 